\title{
アカガシ幼苗の生産における植栽密度の検討
}

\section{Studies on the Production of Qurcus acuta ThUNB. Seedling}

\author{
養父志乃夫* 中島敦司 ${ }^{*}$
}

\section{Shinobu YABU Atsushi NAKASHIMA}

\begin{abstract}
摘要 : アカガシ幼苗の路地生産における適正な植栽密度を把握するため, $1 \mathrm{~m}^{2}$ 当たり $36,64,121$ 本 の 2 年生苗を等間隔で植え付けた。その結果, 成長が終了した 12 月の時点において， 36 本区では, 供試植物の樹高, 樹冠幅, 地際直径の平均值が 121 本区よりも大きくなる傾向が認められた。かい, 平均樹高は 121 本区の $50 \mathrm{~cm}$ に対し 36 本区の $59 \mathrm{~cm}$ ，地際直径は $6.0 \mathrm{~mm} に$ 対し $7.4 \mathrm{~mm}$, 樹冠幅は $20 \mathrm{~cm} に$ 対 し $24 \mathrm{~cm}$ であり，いずれの測定値も標準偏差の大半が重なり合った。さらに，64，121 本区では 45\% を上回る個体が樹高 50 $60 \mathrm{~cm}$ 以上の階級に含まれ，その個体数は 121 本区で最大となった。この結 果, 固場生産効率を考慮すると、樹高 $50 \mathrm{~cm}$ 程度の幼苗の路地生産には, $1 \mathrm{~m}^{2}$ 当たり 121 本程度の密 植が適していると考えられた。
\end{abstract}

\section{1.はじめに}

緑化需要の増大と用途の多様化に伴い, 多植物種, 多品種にわ たる植物生産の体制づくりが，造園材料業界の急務の課題である。 特に近年では, 生態緑化やビオトープの造成など, 植物群落を復 元, 創出する分野が発展し, 材料の多様化とともに, 産地, 系統, 個体群など，材料の質的な充実を求める要望が強い。緑化植物の 生産技術については, (財) 日本緑化センター（1989，1991， 1994) $)^{4 \sim 6)}$ や関西地区林業試験研究機関連絡協議会 $(1970)^{1)}$ 等に, これまでの知見の多くが整理されている。しかし，これらの文献 に記載されていない植物種も数多く ${ }^{11)}$, 記載内容も経験の域を出 ないものもみられる。今後は, 需要の増加と多様化, 材料として の質的な充実に対処するため, 植栽密度に対する種の反応の違い などを活用した効率的な生産技術の体系化が求められる。このよ うな状況から, 養父ら ${ }^{9.10)}$ はオオスギゴケ，チャボリュウノヒゲ 等の緑化植物としての生産手法を検討してきた。

本論では，これまで幼苗生産に関する知見がほとんどみられな いアカガシ Quercus acuta THUNB, を対象に，密度を違えた 2 年生幼苗の植栽実験を行い, 樹高 $50 \mathrm{~cm}$ クラスの幼苗の路地生産 に適した植栽密度を把握したので，その結果を報告する。なお， ここでいう幼苗とは, 中型から大型コンテナ樹木の植え付けに用 いる苗木を指す。また，樹高 $50 \mathrm{~cm}$ の幼苗を基準とした理由は，

(財)建設物価調查会 $(1996)^{2)}$ におけるアラカシ，シラカシ等の 常緑広葉樹高木の最低規格が, 樹高 $50 \mathrm{~cm}$ として示されているこ とによる。

さらに, 本種は, ヤブコウジースダジイ群集やアカガシーミヤ マシキミ群集といった照葉樹林の主な構成種に含まれることから, 生態緑化への活用が期待されるほか, 温量指数 90 未満の寒冷地 や乾燥条件にも耐えることから ${ }^{8,9}$, 今後は, 緑化用植物としての 活用も検討される。

本研究を行った際, 鹿児島大学農学部石井弘教授に御指導いた だき，また，附属高隈演習林の馬田英隆講師，ならびに鹿本キリ スト協会の原口泉氏のご協力を得た。ここにお礼申し上げる。

\section{2. 材料および方法}

鹿児島市内にある鹿児島大学農学部内の苗畑（標高約 $3 \mathrm{~m} ）$ に おいて, 1990 年 2 月 8 日, 直径 $12 \mathrm{~cm}$ の育苗ポットにアカガシの 堅果を 1 粒ずつ播種し幼苗を育成した。播種に供した土壤は，未
表ー 1 植栽した時点*のアカガシの形状

\begin{tabular}{cll}
\hline 植栽密度 & \multicolumn{1}{c}{ 樹高 } & 主軸直径 \\
\hline 36 個体 $/ \mathrm{m}^{2}$ & $14.1^{\mathrm{a} \pm 6.2 \mathrm{~cm}}$ & $3.6^{\mathrm{a} \pm 1.1 \mathrm{~mm}}$ \\
64 & $13.9^{\mathrm{a}} \pm 5.2$ & $3.6^{\mathrm{a} \pm 1.0}$ \\
121 & $13.8^{\mathrm{a} \pm 5.7}$ & $3.5^{\mathrm{a}} \pm 1.0$ \\
\hline
\end{tabular}

*：1991年5月7日の状態（各区とも3反復）

a : $t$ 検定による検定結果では有意差は認められなかった

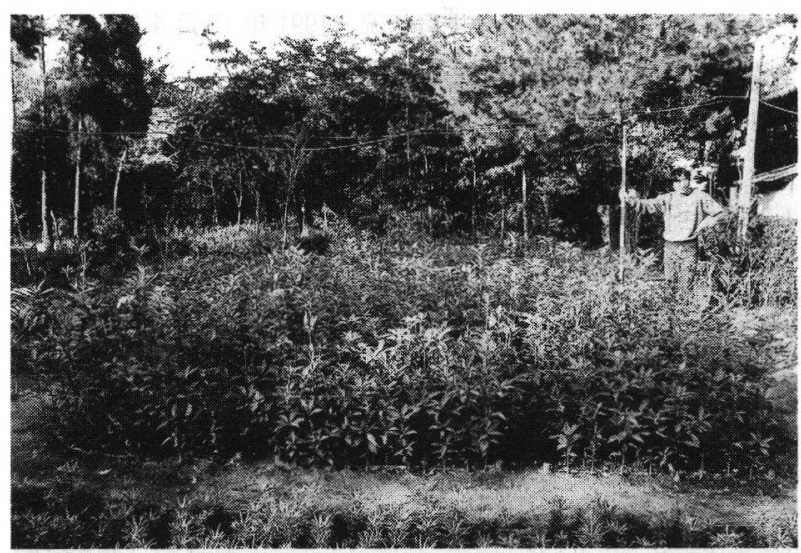

写真 -1 試験值の概況（1991 年 12 月 4 日）

熟火山灰黒色堆積土（シラス）であり，施肥は行わず，管理とし ては灌水と除草, 虫害防除のための薬剤散布を適宜害施した。ま た, 使用した堅果は, 1989 年 10 月から 11 月に, 鹿児島県垂水 市内の鹿児島大学農学部附属高隈演習林（標高約 $400 \mathrm{~m}$ ) におい て, 落下して間もない虫くいの無いものを採集し, 透明のビニル袋に入れ， $5{ }^{\circ} \mathrm{C}$ 冷蔵庫内で保存しておいたものである。

1991 年 4 月 4 日, 目視により健全と判断されたアカガシ幼苗 の中から, 表一 1 に示したほぼ均一な個体を選抜した。次に, 面 積 $1 \mathrm{~m} \times 1 \mathrm{~m}$ で $10 \mathrm{~cm}$ の高さに慾立てした $9 つ$ の試験区に，碁盤 の目に合わせ等間隔で 36 個体を植え付ける 36 本区, 同様に碁盤 目に 64 本を植え付ける 64 本区，さらに，121 本区を，それぞれ， 3 反復ずつ設定し, 選抜した計 663 本の幼苗（表一 1) を植栽し た。植え付けた個体の間隔は, 36 本区と 64 本区では, $16.7 \mathrm{~cm}$ と

*和歌山大学システム工学部環境システム学科 


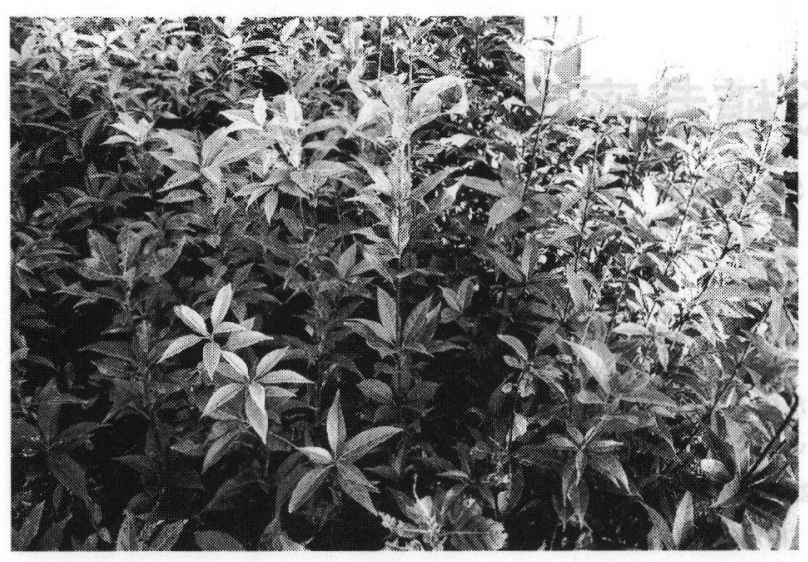

写真 -236 本区の生育状況（1991 年 12 月 4 日）

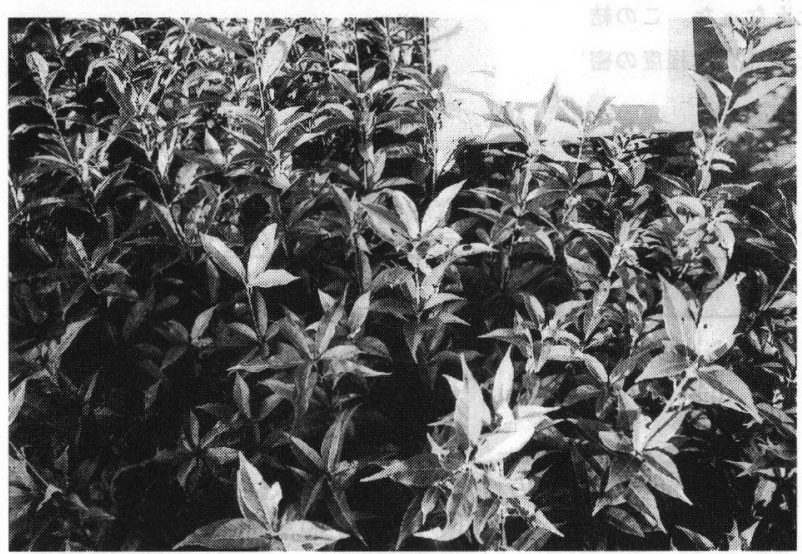

写真- 364 本区の生育状況（1991 年 12 月 4 日）

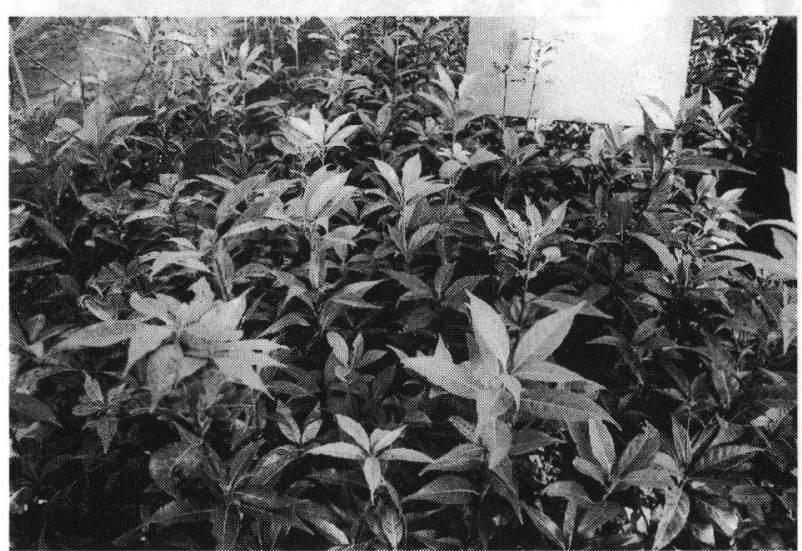

写真－4 121 本区の生育状況（1991 年 12 月 4 日）

$12.5 \mathrm{~cm}, 121$ 本区では $9 \mathrm{~cm}$ であった。各試験区の間隔は, 東西で $30 \mathrm{~cm}$, 南北で $50 \mathrm{~cm}$ とした。なお, 試験地の概況は写真 -1 に示 した通りである。

試験区の土壌は，未熟火山灰黒色堆積土（シラス）であり，植 え付け前に地下約 $25 \mathrm{~cm}$ まで耕耘しながら, $1 \mathrm{~m}^{2}$ 当たり $50 \mathrm{~g}$ の牛 糞堆肥を施した。供試植物への管理は, 初期灌水以外は, 適宜, 除草を行うだけとした。また, 最寄りの鹿児島地方気象台におけ る年降水量と年平均気温は, それぞれ $2,421 \mathrm{~mm}$ と $17.7^{\circ} \mathrm{C}$ あ゙あ ${ }^{7)} 。$

1991 年 5 月 7 日から 12 月 4 日までの期間, 各月の上旬に 1 回, 3 段階に密度を違えた 36 本，64 本，121 本区の各試験区から， 1 植栽密度区当たり最外部に位置する植物を除いた 30 個体をラ ンダム抽出し, 樹高, 地際部の主軸直径（以下，地際直径とする） を測定した。さらに, 最終測定日の 12 月 4 日には, 各植栽密度 毎に全個体を対象に, 樹高, 地際直径, 最大樹冠幅（以下, 樹冠
表 -2 植栽密度別にみた 2 年生アカガシの生存率*

\begin{tabular}{clclll}
\hline 植栽密度 & 生存率 & 枯死個体数 & & 枯死日 & \\
\hline 36 本区 & $99.1 \%$ & 1 & $8 / 7$ & & \\
64 & 99.5 & 1 & $5 / 3$ & & \\
121 & 98.9 & 4 & $6 / 5,8 / 7$, & $11 / 6$, & $12 / 4$ \\
\hline
\end{tabular}

*：1991年12月 4 日までの結果（各区とも3 反復）

幅とする), 1 個体当たり 3 枚の葉の最大葉長と最大葉幅を測定 した。なお,ここで測定した葉は, 植物体の頂部から 2 節目付近 に着生していたものである。

3. 結果亡考察

(1) 生存率

植栽後 1 年間が経過した最終測定日の 1991 年 12 月時の生存率 は，植栽密度の違いを問わず，いずれの試験区においても $98 \%$ を越え， 36 本区，64 本区および最も密度の高い 121 本区におい ても個体間の競争による枯死はほとんど認められなかった（表一 2 , 写真 $-2 \sim 4$ )。

(2) 樹高, 地際直径, 樹冠幅

植栽後の樹高と地際直径の成長過程を植栽密度によって比較す ると, 両者の平均值は, 図- 1 に示したように, ともに植栽後 3 ヶ月目前後から， 121 本 $<64$ 本 $<36$ 本区の順に大きく成長する 傾向を示した。

図一 2 に示したように，測定最終日における 121 本区の供試植 物の平均樹高は $48.1 \pm 18.1 \mathrm{~cm}$ であり, 64 本区と 36 本区の樹高よ りあ小さいと判断された（ $p \leqq 0.05 ， t$ 検定による，以下の検定む
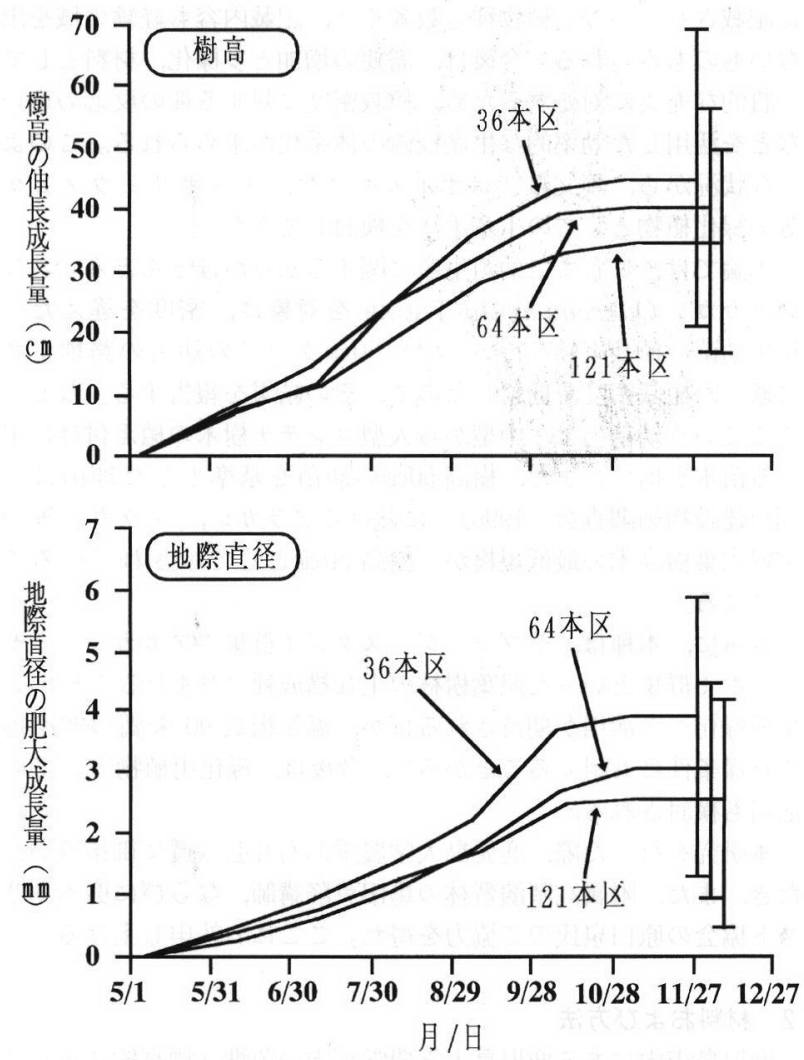

図-1 植栽密度の違いが 2 年生アカガシの樹高と地際直径の成 長経過に及ぼす影響

注 1 : 縦線は測定終了時の 1991 年 12 月 4 日の標準偏差を示す

注 $2 ：$ 代表 30 個体の結果 

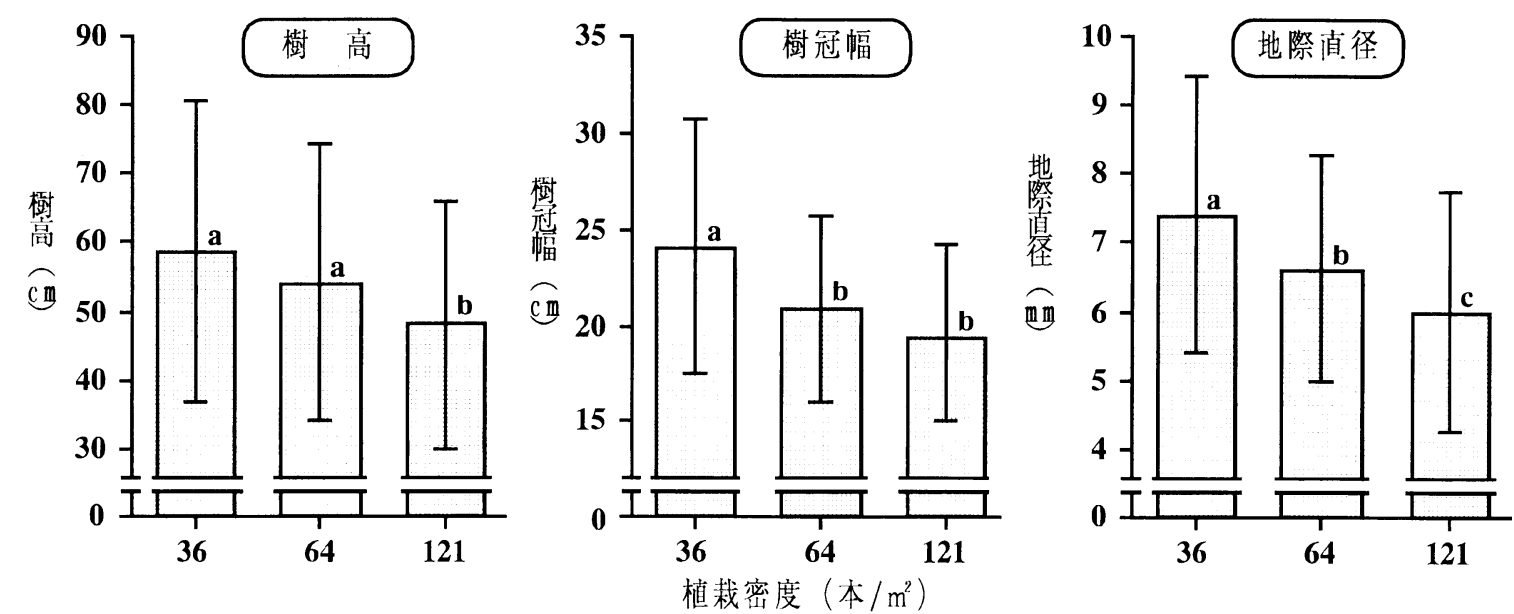

図ー2 植栽密度別にみた 2 年生アカガシの樹高, 樹冠幅, 地際直径（測定終了時の 1991 年 12 月 4 日の状況）

注 $1:$ 縦線は標準偏差を示す

注 $2:$ : ずれの植栽密度区とも、外周部の植物は除外

注 3 : 図内の $a, b, c$ は $\mathrm{t}$ 検定による検定結果を示す $(a>b>c, p \leqq 0.05)$
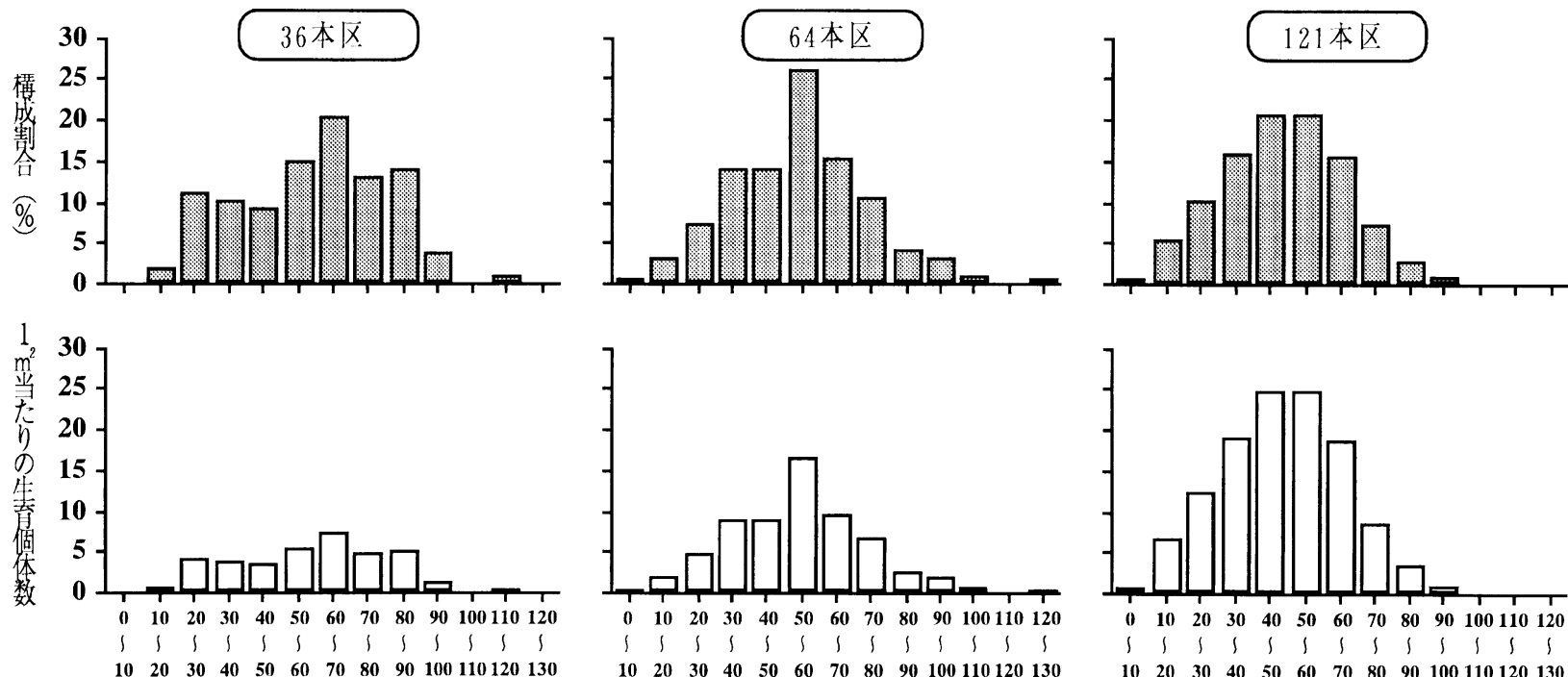

樹高の階級 $(\mathrm{cm})$

図一３植栽密度別にみた 2 年生アカガシの樹高の構成割合（上図）と $1 \mathrm{~m}^{2}$ 当たりの生育個体数（下図）

注 $1:$ 測定終了時の 1991 年 12 月 4 日の状況

注 2：いずれの密度区とも、外周部の植物は除外

同様)。これに対し，64 本区と 36 本区の平均樹高の間には有意

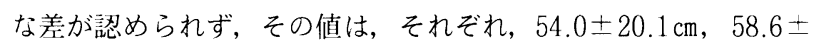
$22.0 \mathrm{~cm}$ であった。また, 平均樹冠幅は, 121 本区 $<64$ 本区 $<36$ 本区の順に大きくなり $(p \leqq 0.05)$ ，その值は，121 本区で $19.3 \pm$ $4.9 \mathrm{~cm}, 64$ 本区で $20.9 \pm 4.9 \mathrm{~cm}, 36$ 本区では $24.0 \pm 6.7 \mathrm{~cm}$ であった さらに, 121 本区の平均地際直径は $6.0 \pm 1.8 \mathrm{~mm}$ であり, 64 本区の $6.6 \pm 1.6 \mathrm{~mm}$ との間には有意な差が認められなかった。これに対し, 36 本区の平均地際直径は $7.4 \pm 2.0 \mathrm{~mm}$ であり, 121 本区ならびに 64 本区よりも大きいと判断された（ $p \leqq 0.05 ） 。$

これらの結果, 36 本区では, 供試植物の樹高, 樹冠幅, 地際 直径の平均值が 121 区よりも大きくなる傾向が認められた。しか し, 樹高, 樹冠幅, 地際直径ともに，36，64，121 本区の標準偏 差が大きく重なり合った。そこで，この重なりの部分に含まれた 個体の割合を，36，64，121 本区の順にみると，樹高で40.7，56.8， $57.8 \%$, 樹冠幅で 48.1，53.6，44.9\%, 地際直径では $36.1 ， 47.9$, 43.8\%であった。このように, 各区ともに, 樹高, 樹冠幅, 地際 直径の標準偏差の重なり合う部分に含まれる個体は多く, $1 \mathrm{~m}^{2}$ 当 たり 36〜121 本の植栽密度の範井では, 密度効果の影響は明確に
表 -3 植栽密度別にみた 2 年生アカガシの樹植形“

\begin{tabular}{ccc}
\hline 植栽密度 & $H / S$ & $H / D$ \\
\hline 36 本区 & $2.46^{\mathrm{a}} \pm 0.86$ & $78.17^{\mathrm{a}} \pm 17.15$ \\
64 & $2.51^{\mathrm{a}} \pm 0.75$ & $70.01^{\mathrm{a}} \pm 16.73$ \\
121 & $2.40^{\mathrm{a}} \pm 0.64$ & $76.73^{\mathrm{a}} \pm 14.02$ \\
\hline
\end{tabular}

*: 1991年12月 4 日の結果（各区とも 3 反復）

$H ：$ 樹高, $S$ ：樹冠幅, D：地際直径

$a ： t$ 検定による検定結果では有意差は認めれなかった

示されないものと考えられた。

\section{(3) 樹形, 葉形}

最終測定日における樹高と樹冠幅との比，ならびに樹高と地際 直径との比を表－3に，また，葉長と葉幅の関係を表一 4 に示し たが，いずれの值も 36 本， 64 本，121 本区のあいだで明瞭な差 がみられず, アカガシ 2 年生苗の 1 年間の成長過程では, 樹形や 葉形に密度効果の影響がほとんど現れないものと判断された。

\section{(4) 樹高の階級別構成割合}

全個体の樹高の階級別構成割合を，植栽密度別にみると，図一 
表 -4 植栽密度別にみた 2 年生アカガシの葉形・

\begin{tabular}{cll}
\hline 植栽密度 & 葉長 & 葉幅 \\
\hline 36 本区 & $8.3^{\mathrm{a}} \pm 1.4 \mathrm{~cm}$ & $2.7^{\mathrm{a}} \pm 0.4 \mathrm{~cm}$ \\
64 & $8.3^{\mathrm{a} \pm 1.2}$ & $2.7^{\mathrm{a}} \pm 0.4$ \\
121 & $8.5^{\mathrm{a} \pm 1.3}$ & $2.6^{\mathrm{a}} \pm 0.4$ \\
\hline
\end{tabular}

*：1991年12月 4 日の結果（各区とも3反復）

$a ： t$ 検定による検定結果では有意差は認めれなかった

3 に示したように，36 本区のモードは 60〜 $70 \mathrm{~cm}$ の階級にあり， 樹高 $50 \mathrm{~cm}$ 以上の個体数は $1 \mathrm{~m}^{2}$ 当たり 23 個体（全個体の約 $65 \%$ ） であった。また， 64 本区のモードは 50〜 60 cmの階級にあり，樹 高 $50 \mathrm{~cm}$ 以上の個体数は $1 \mathrm{~m}^{2}$ 当たり 37 個体（全個体の約 $58 \%$ ）で

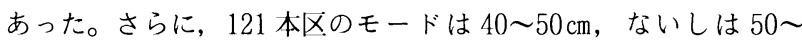
$60 \mathrm{~cm}$ の階級にあり，樹高 $50 \mathrm{~cm}$ 以上の個体は $1 \mathrm{~m}^{2}$ 当たり 57 個体 （全個体の約 47\%）であった。

\section{(5) 樹高成長の時期}

樹高の成長期間は，図- 1 に示したように，概社測定開始日か ら最終日の 12 月初旬までであった。ただし，樹高伸長した個体 の割合を月別にみると（図一 4)，いずれの月で屯 $100 \%$ に達す

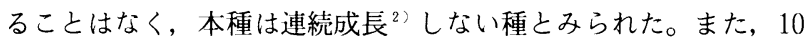
月初旬から 12 月初旬までの期間に樹高成長した個体の出現頻度 は，36，64，121 本区とも前月までよりも明らかに少なく，本種 の樹高成長が旺盛となる時期は，実験をおこなった鹿児島付近で は 4 月〜 10 月初旬までであることが示され，そのピークは植栽 密度の違いを問わず，7月初的から 10 月初旬に現れた（図一 4 )。

\section{4.まとめ}

アカガシの苗木生産における適正な植栽密度を把握するため, 本論では 2 年生の幼苗を用いて植栽実験を行った。その結果, 1 $\mathrm{m}^{2}$ 当たり 36〜121 本の植栽密度の範囲でみると, 本種の個体間の 競争による影響は 1 年間では明瞭にあらわれず，その年内に樹高 $50 \mathrm{~cm}$ 越える苗木を生産するためには, 南九州地方では, $1 \mathrm{~m}^{2}$ 当 たり 36 本，64 本植えよりも，121 本程度の高密度植栽の方が， 単位面積当たりの生産効率は高いものと考えられた。
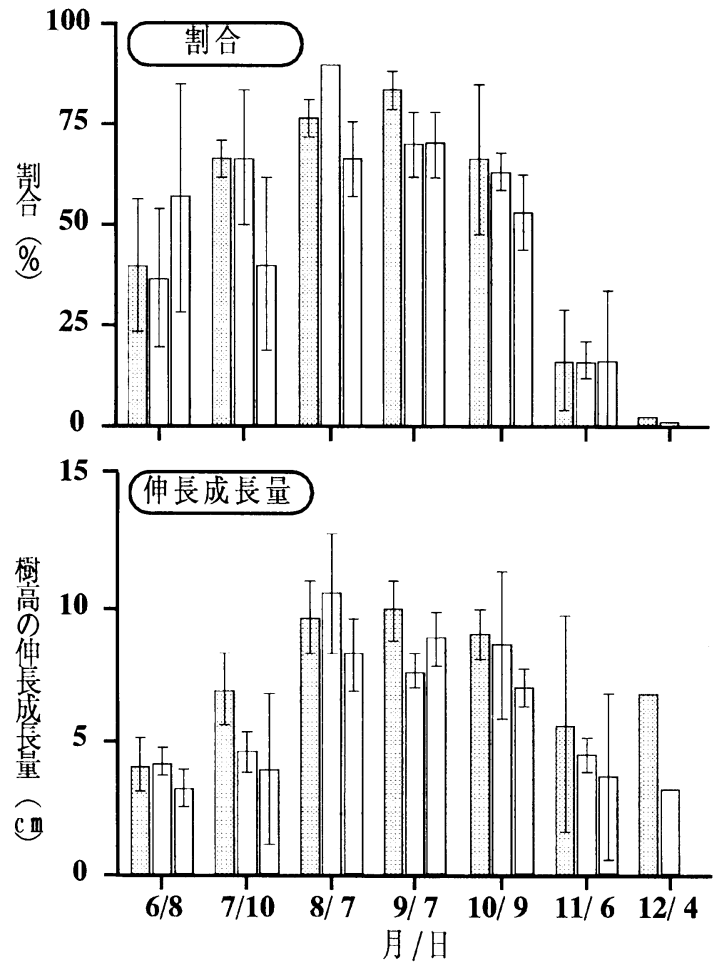

図ー4 植栽密度の違いによる 2 年生アカガシの樹高伸長を示し た個体の月別の割合と 1 カ月間の伸長速度

注 1 : 各日とも $36(\boldsymbol{\square}), 64(\square), 121$ 本区 $(\square)$ を示す 注 2 : 伸長成長量は伸長の認められた個体の平均値（外周部の植 物は除外)

注 3 : 縦線は標準偏差を示す

注 $4: 8$ 月 7 日の 64 本区では 3 反復とも同じ割合であった 注 $5: 12$ 月 4 日は 36,64 本区ともに 1 苗床のみで伸長が認めら れた

\section{参考文献}

1 ）関西地区林業試験研究機関連絡協議会 育苗部会編（1970）: 樹木のふやし方一 タネ・ホとりから苗木まで : 農林出版 株式会社, pp340

2) Kramer P.L. - Kozlowski T.T. (1974) : Physiology of woody plants : Academic Press, 436-565

3 ）（財)建設物価調查会（1996）：建設物 価平成 8 年 No.842, 334-335

4)（財）日本緑化センター（1989）：緑化 樹木の生産技術 第 1 集 常緑広葉樹編 pp200

5 )（財)日本緑化センター (1991): 緑化 樹木の生産技術 第 2 集 落葉広葉樹編, pp200

6)（財)日本緑化センター (1994)：緑化 樹木の生産技術 第 3 集 針葉樹・特殊 樹類編, pp200

7 ) 竹中則夫 (1981)：照葉樹林構成種群 の分布要因の解析. 温度要内 : 神戸女 学院大学論集 28(1), 201-229

8 ) 竹中則夫 (1981): 照葉樹林構成種群 の分布要因の解析 III. 温度・乾湿度気
候及び積雪気像要因 : 神戸女学院大学 論集 28（3 )，113-130

9 ）養父志乃夫・中島敦司ほか（1990）: オオスギゴケを用いた張り苔の生産手 法に関する研究：造園雑誌 53(5), 97 $-102$

10）養父志乃夫・石川格ほか（1991）: 組 織培養法によるチャボリュウノヒゲの 大量増殖に関する研究：造園雑誌 54 (5), $114-119$

11）山中寅文（1975）：植木の実生と育て 方 : 誠文堂, pp256

Summary: The second year seedlings of Qurcus acuta THUNB. were planted to 36, 64 and 121 plants per square meter. It was studied of the most efficient density for producting large seedlings whose heights were over $50 \mathrm{~cm}$. Three growth parameters of seedlings were measured every one month from May to December. They were tree heights, tree spreads and stem diameters at ground level. All growth parameters at beds with 36 plants were greater than that of beds with 121 plants in December when the annual growth were finished. For example, plant heights were 58.6 and $48.1 \mathrm{~cm}$, tree spreads were 24.0 and $19.3 \mathrm{~cm}$, and stem diameters were 7.4 and $6.0 \mathrm{~mm}$. The standard deviations in each growth parameter between beds with 36 plants and 121 plants followed another. The plants whose heights were over $50 \mathrm{~cm}$ exceeded 45 percentages at beds with 64 and 121 plants. And there were the greatest number of plants at beds with 121 plants. It indicated that the most efficient planting density that produced large seedlings of $Q$. acuta were planted to 121 plants per square meter. 